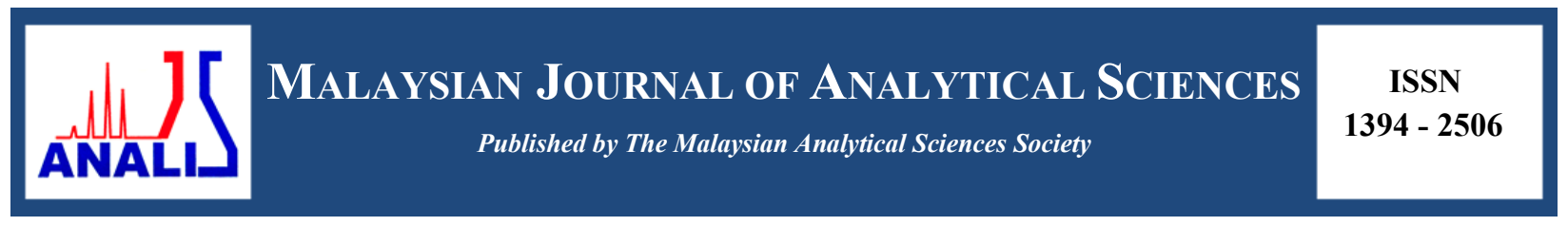

\title{
PREPARATION OF LANTHANUM STRONTIUM COBALT OXIDE POWDER BY A MODIFIED SOL-GEL METHOD
}

\section{(Penyediaan Serbuk Lantanum Strontium Kobalt Oksida Melalui Kaedah Sol-Gel Terubahsuai)}

\author{
Abdullah Abdul Samat ${ }^{1}$, Mahendra Rao Somalu ${ }^{1 *}$, Andanastuti Muchtar ${ }^{1,2}$, Nafisah Osman $^{3}$ \\ ${ }^{I}$ Fuel Cell Institute \\ ${ }^{2}$ Department of Mechanical and Materials Engineering, Faculty of Engineering and Built Environment \\ Universiti Kebangsaan Malaysia, 43600 UKM Bangi, Selangor, Malaysia \\ ${ }^{3}$ Faculty of Applied Sciences, \\ Universiti Teknologi MARA, 02600 Arau, Perlis, Malaysia \\ *Corresponding author: mahen@ukm.edu.my
}

Received: 21 October 2015; Accepted: 14 June 2016

\begin{abstract}
A simple low temperature synthesis route has been presented for the preparation of single perovskite phase of $\mathrm{La}_{0.6} \mathrm{Sr}_{0.4} \mathrm{CoO}_{3-\delta}$ (LSCO) for cathode application in intermediate temperature proton conducting solid oxide fuel cell (SOFC). A wet chemical method namely a modified sol-gel method has been applied in this work. In this method, a combined citric acid and ethylenediaminetetraacetic acid (EDTA) has been used as a chelating agent. Ethylene glycol (EG) and activated carbon (AC) have been used as surfactants in this process. The synthesized powders were characterized by X-ray diffractometer (XRD), scanning electron microscope (FESEM) equipped with energy dispersive X-ray (EDX) spectrometer and particle size analyzer (PSA) for phase formation, morphology and particle size analysis, respectively. XRD result revealed that a single LSCO perovskite phase for both surfactants formed at calcination temperature of $900{ }^{\circ} \mathrm{C}$. The produced single phase powders consist of homogeneous and almost identical shape of particles as shown in SEM images. However, the powder prepared using EG has a smaller average particle size diameter as compared with the powder prepared using AC which is $149 \mathrm{~nm}$ and $190 \mathrm{~nm}$, respectively.
\end{abstract}

Keywords: modified sol-gel, surfactant, cathode, solid oxide fuel cell, single perovskite phase of $\mathrm{La}_{0.6} \mathrm{Sr}_{0.4} \mathrm{CoO}_{3-\delta}$

\section{Abstrak}

Satu kaedah sintesis ringkas pada suhu rendah telah dibentangkan untuk menyediakan fasa tunggal perovskit $\mathrm{La}_{0.6} \mathrm{Sr}_{0.4} \mathrm{CoO}_{3-\delta}$ (LSCO) bagi aplikasi katod di dalam konduktor proton sel bahan api oksida pepejal (SFOP) suhu sederhana. Satu kaedah kimia basah, iaitu, kaedah sol-gel terubahsuai telah digunakan dalam penyelidikan ini. Melalui kaedah ini, gabungan asid sitrik dan asid atelindiamintetrasetik (EDTA) telah digunakan sebagai agen pengikat. Etilena glikol (EG) dan karbon teraktif (AC) telah digunakan sebagai surfaktan dalam proses ini. Serbuk yang disintesis telah dicirikan dengan menggunakan pembelauan sinar-X (XRD), mikroskop elektron pengimbas (SEM) dilengkapi dengan spektroskopi sinar-X sebaran tenaga (EDX) dan penganalisis saiz zarah (PSA) bagi analisis pembentukan fasa, morfologi dan saiz zarah, masing-masing. Keputusan XRD menunjukkan fasa tunggal perovskit LSCO bagi kedua-dua surfaktan telah terbentuk pada suhu pengkalsinan $900{ }^{\circ} \mathrm{C}$. Serbuk berfasa tunggal yang terhasil terdiri daripada zarah yang homogen dan mempunyai bentuk yang hampir sama seperti ditunjukkan dalam imej SEM. Walau bagaimanapun, serbuk yang dihasilkan menggunakan EG mempunyai purata diameter saiz zarah yang lebih kecil iaitu $149 \mathrm{~nm}$ berbanding serbuk yang dihasilkan menggunakan AC iaitu $190 \mathrm{~nm}$.

Kata kunci: sol-gel terubahsuai, surfaktan, katod, proton sel bahan api oksida pepejal, fasa tunggal perovskit $\mathrm{La}_{0.6} \mathrm{Sr}_{0.4} \mathrm{CoO}_{3-\delta}$ 


\section{Abdullah et al: PREPARATION OF LANTHANUM STRONTIUM COBALT OXIDE POWDER BY A MODIFIED SOL-GEL METHOD}

\section{Introduction}

Nowadays, solid oxide fuel cells (SOFCs) have received considerable attention worldwide. It has been deemed as one of the most promising future power generation as if offers few remarkable advantages including high energy conversion efficiency, low/zero pollutant emission and fuel flexibility compared to the conventional energy power generator. The challenge in the SOFC development is to lower the operating temperature from high $\left(800-1000{ }^{\circ} \mathrm{C}\right)$ to intermediate $\left(500-700{ }^{\circ} \mathrm{C}\right)$ temperatures. The fabrication cost is then expected to be reduced which would boost the commercialization of such energy conversion devices [1,2].

One the most promising SOFC technologies operating at intermediate temperature is proton conducting SOFC $\left(\mathrm{H}^{+}-\right.$ SOFC). However, only few reports have dealt with $\mathrm{H}^{+}$-SOFC technology especially in cathode materials for the $\mathrm{H}^{+}-$ SOFC in the literature [3-6]. In this context, our main goal is to synthesis suitable cathode materials for the $\mathrm{H}^{+}$SOFC.

In the last two decades, cobaltite oxides have been widely studied due to the fact that many of these compounds have shown good electrical conductivity and remarkable thermoelectric properties that could be used in practical applications. Among these oxides, lanthanum cobaltite, $\mathrm{LaCoO}_{3}$-based materials are frequently employed as cathode material for $\mathrm{H}^{+}$-SOFC. The material does not form oxygen vacancies at temperatures below $600{ }^{\circ} \mathrm{C}$ and it is therefore a pure electronic conductor in the expected operating temperature range of the $\mathrm{H}^{+}$-SOFC. Additionally, the material has shown to be stable with no phase changes were observed after 350 hours stability test at $600{ }^{\circ} \mathrm{C}$ in air as well as in humidified air $\left(\rho \mathrm{H}_{2} \mathrm{O}=0.2 \mathrm{~atm}\right)$ [4]. Furthermore, the $\mathrm{LaCoO}_{3}$ does not react with solutions of barium cerate-zirconate at temperatures below $1100{ }^{\circ} \mathrm{C}$ due to its stability in air and wet atmosphere [7].

To this date, $\mathrm{LaCoO}_{3}$-based cathode material such as strontium-doped $\mathrm{LaCoO}_{3}, \mathrm{LaSrCoO}_{3}$ is still lack in the literature particularly for $\mathrm{H}^{+}$-SOFC application which uses barium cerate-zirconate as its electrolyte. Therefore, in this present work, a ceramic based on $\mathrm{LaCoO}_{3}$ material which is $\mathrm{La}_{0.6} \mathrm{Sr}_{0.4} \mathrm{CoO}_{3-\delta}$ (LSCO) has been prepared to be used as cathode material for $\mathrm{H}^{+}$-SOFC application later. The LSCO material was synthesized by a modified sol-gel method. This method allows the preparation of a single crystalline materials at relatively low processing temperature with good stoichiometry control and preserves the homogeneity of the composition along with relatively large surface area after heat treatment $[8,9]$. Two different surfactants namely, ethylene glycol (EG) and activated carbon (AC) have been used in producing the LSCO materials and their effects on phase formation, morphology and particle size of the produced powders have been presented in this work.

\section{Materials and Methods}

$\mathrm{La}_{0.6} \mathrm{Sr}_{0.4} \mathrm{CoO}_{3-\delta}$ (LSCO) powder was prepared via a modified sol-gel method. Citric acid and ethylenediaminetetraacetic acid (EDTA) was used as a combined chelating agent; ethylene glycol (EG) and activated carbon (AC) were used as surfactants. Analytical grade of metal nitrate salts of lanthanum, $\mathrm{La}\left(\mathrm{NO}_{3}\right)_{3} \cdot 6 \mathrm{H}_{2} \mathrm{O}$, strontium, $\mathrm{Sr}\left(\mathrm{NO}_{3}\right)_{2}$ and cobalt, $\mathrm{Co}\left(\mathrm{NO}_{3}\right)_{3} \cdot 6 \mathrm{H}_{2} \mathrm{O}$ were used as precursor materials. A mixture of these precursor materials was firstly dissolved in $100 \mathrm{~mL}$ deionized water. Then, calculated amount of citric acid was added into the solution mixture with stirring. Next, calculated amount of EDTA was slowly added into the solution mixture. After that, $\mathrm{pH}$ of the solution was adjusted to be 0.5 . Finally, the respective surfactant (EG and AC) was added and the solution was continuously stirred and heated for several hours to obtain a viscous gel. The resulting viscous gel was dried at $150^{\circ} \mathrm{C}\left(12\right.$ hours) and $250^{\circ} \mathrm{C}$ (5 hours) accordingly. The as-synthesized powder was calcined at temperatures of $500,600,700,800$ and $900{ }^{\circ} \mathrm{C}$ with heating/cooling rate of $5{ }^{\circ} \mathrm{C} \mathrm{min}^{-1}$ for 5 hours. The LSCO prepared with the EG and AC as surfactant and caclcined at different calcination temperatures are labelled as EG500, EG600, EG700, EG800, EG900, AC500, AC600, AC700, AC800 and AC900, respectively.

X-ray diffractometer (XRD Bruker D8 Advance) using a monochromatic $\mathrm{Cu}-\mathrm{K}_{\alpha}$ radiation source $(\lambda=0.1540 \mathrm{~nm})$ with Ni-filtered was used to confirm the phase formation of LSCO perovskite powder. The XRD was operated at 40 $\mathrm{kV}$ and $30 \mathrm{~mA}$ using a step scan procedure of $0.02^{\circ} \mathrm{s}^{-1}$ for 2 theta $(\theta)$ ranging from $20^{\circ}$ to $80^{\circ}$. The percentage of perovskite phase present in the calcined powders was calculated using equation (1) as proposed by Swarts and Shrout [10].

$$
\text { Perovskite phase }=\frac{I_{p}}{I_{p}+I_{\mathrm{m}}} \times 100 \%
$$


The $I p$ refers to the maximum intensity of the perovskite phase and $I m$ is the maximum intensity of the impurity phases. Morphology of the powder was examined by a Merlin Compact Zeiss field emission scanning electron microscope (FESEM) equipped with energy dispersive X-ray (EDX) spectrometer. The imaging was performed in Secondary Electron (SEI) mode using an accelerating voltage of $15 \mathrm{kV}$ at magnification of 15000 times. Particle size distribution analysis of the powders was done using Nano-ZS Particle Size Analyzer (PSA) manufactured by Malvern using deionized water as a dispersant.

\section{Phase formation analysis}

\section{Results and Discussion}

Figures 1 and 2 show the XRD profiles of LSCO powders prepared with different surfactants and calcined at different calcination temperatures, respectively. Both of the XRD profiles have almost similar patterns. The strongest peaks of all the XRD patterns were matched with Joint Committee of Powder Diffraction Standards (JCPDS) file no. 48-0121 with cubic (Pm-3m) structure. The pronounce peaks can be indexed to their Miller indices (hkl) of (100), (110), (111), (200), (210), (211), (220), (300) and (310), accordingly. Besides that, some additional peaks corresponded to the trace of impurity phases such as cobalt oxide $(\mathrm{CoO})$, strontium oxide $(\mathrm{SrO})$ and strontium cobalt oxide $\left(\mathrm{SrCoO}_{\mathrm{x}}\right)$ were also presence in the XRD patterns of the calcined powders.

As the calcination temperature increases, the peaks intensity in both XRD profiles was further enhanced and become the dominant phase. The calcined powders at $500,600,700$ and $800{ }^{\circ} \mathrm{C}$ have shown weak crystallinity of the LSCO perovskite phase since the trace of the impurity phases appeared in their XRD patterns. The full crystallization of a single perovskite phase of LSCO was formed at calcination temperature of $900{ }^{\circ} \mathrm{C}$ for the powders prepared using both surfactants. The works done by Tao et al. [8], Heel et al. [11] and Acuña et al. [12] also obtained a single phase of the LSCO at calcination temperature of $900{ }^{\circ} \mathrm{C}$ but using different synthesis methods namely citrate-EDTA, flame spray and free-drying, accordingly. Furthermore, as the calcination temperature increases, the calculated amount of perovskite phase percentage also increased. A summary of phase formation analysis was presented in Table 1.

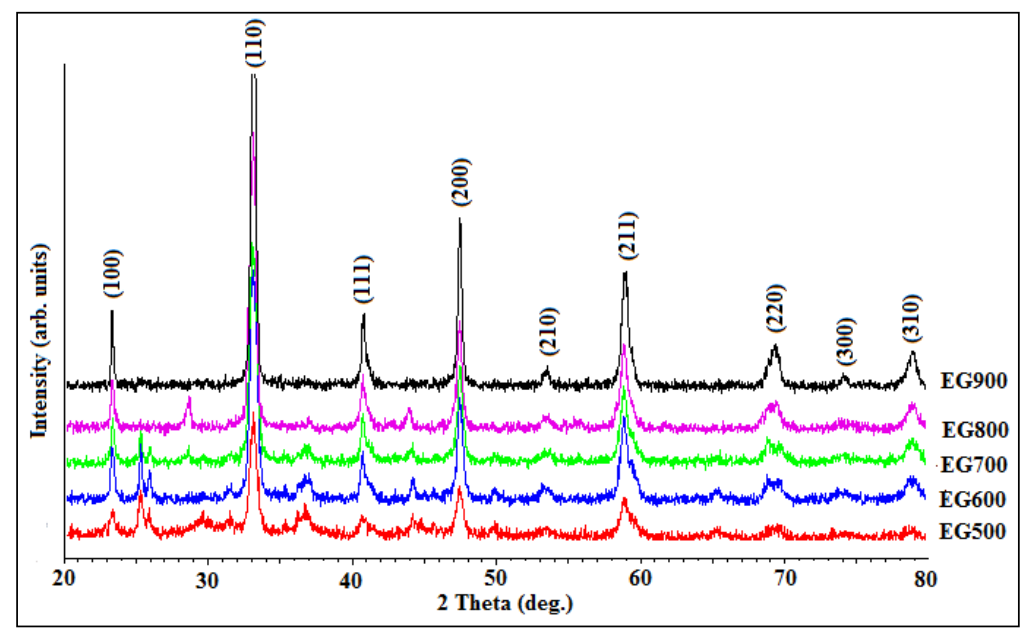

Figure 1. XRD patterns of the powders after calcined at various temperatures prepared using ethylene glycol (EG) as a surfactant 


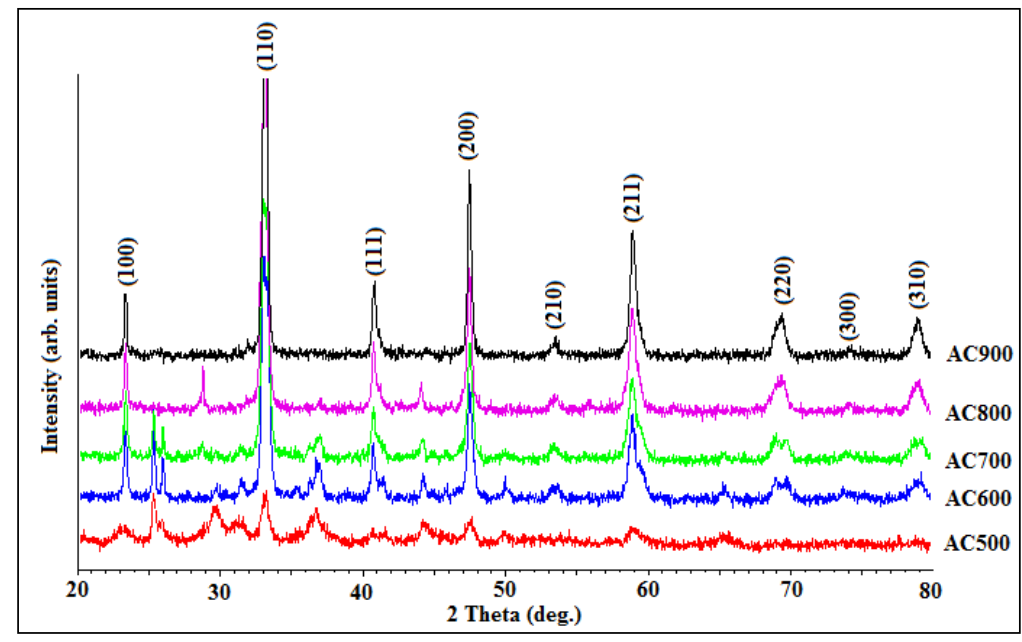

Figure 2. XRD patterns of the powders after calcined at various temperatures prepared using activated carbon (AC) as a surfactant

Table 1. A summary of phase formation analysis

\begin{tabular}{|c|c|c|}
\hline Sample & Crystalline Phase & $\begin{array}{c}\text { Percentage of Perovskite Phase } \\
(\%)\end{array}$ \\
\hline EG500 & $\mathrm{LSCO}, \mathrm{CoO}, \mathrm{SrO}, \mathrm{SrCoO}_{\mathrm{x}}$ & 73.06 \\
\hline EG600 & $\mathrm{LSCO}, \mathrm{CoO}, \mathrm{SrO}, \mathrm{SrCoO}_{\mathrm{x}}$ & 79.47 \\
\hline EG700 & $\mathrm{LSCO}, \mathrm{CoO}, \mathrm{SrO}, \mathrm{SrCoO}_{\mathrm{x}}$ & 86.55 \\
\hline EG800 & $\mathrm{LSCO}, \mathrm{CoO}, \mathrm{SrCoO}_{\mathrm{x}}$ & 90.25 \\
\hline EG900 & LSCO & 100.00 \\
\hline AC500 & $\mathrm{LSCO}, \mathrm{CoO}, \mathrm{SrO}, \mathrm{SrCoO}_{\mathrm{x}}$ & 50.57 \\
\hline AC600 & $\mathrm{LSCO}, \mathrm{CoO}, \mathrm{SrO}, \mathrm{SrCoO}_{\mathrm{x}}$ & 72.39 \\
\hline AC700 & $\mathrm{LSCO}, \mathrm{CoO}, \mathrm{SrO}, \mathrm{SrCoO}_{\mathrm{x}}$ & 84.34 \\
\hline AC 800 & $\mathrm{LSCO}, \mathrm{CoO}, \mathrm{SrCoO}_{\mathrm{x}}$ & 89.59 \\
\hline AC900 & LSC0 & 100.00 \\
\hline
\end{tabular}

\section{Powder morphology and particle size distribution analysis}

SEM micrographs of the single LSCO perovskite phase powders of the EG900 and AC900 are shown in Figure 3. The powders consist of homogeneous and almost identical particles. They are basically spherical in shape. The particles are well connected with each other and formed well-bonded porous network. Figures 4 and 5 show the EDX patterns of LSCO in EG900 and AC900 powders, respectively. The figures reveal the presence of lanthanum $(\mathrm{La})$, strontium $(\mathrm{Sr})$, cobalt $(\mathrm{Co})$, oxygen $(\mathrm{O})$ and carbon $(\mathrm{C})$ peaks in the powders.

The analysis of elemental composition of each of the element in the EG900 and AC900 powders is presented in Table 2 and Table 3, accordingly. The weight percent (wt \%) of each element is obtained from the EDX analysis and has been used to calculate the mole fraction. The site fractions were calculated assuming pure $\mathrm{ABO}_{3}$ perovskite phase of LSCO with La and Sr on A-sites and Co only on B-sites. From the table, it can be seen that the elemental fraction of $\mathrm{La} / \mathrm{Sr}$ in the EG900 was close to the nominal fraction of LSCO. However, the elemental fraction of $\mathrm{La} / \mathrm{Sr}$ in the AC900 is slightly deviated from the nominal fraction. Additionally, residual carbon element is higher in the 
AC900 compared to the EG900 as the activated carbon contains many C element. The high residual carbon content might block the $\mathrm{La} / \mathrm{Sr}$ from being detected in the EDX spectrum which then contributes to the deviation.

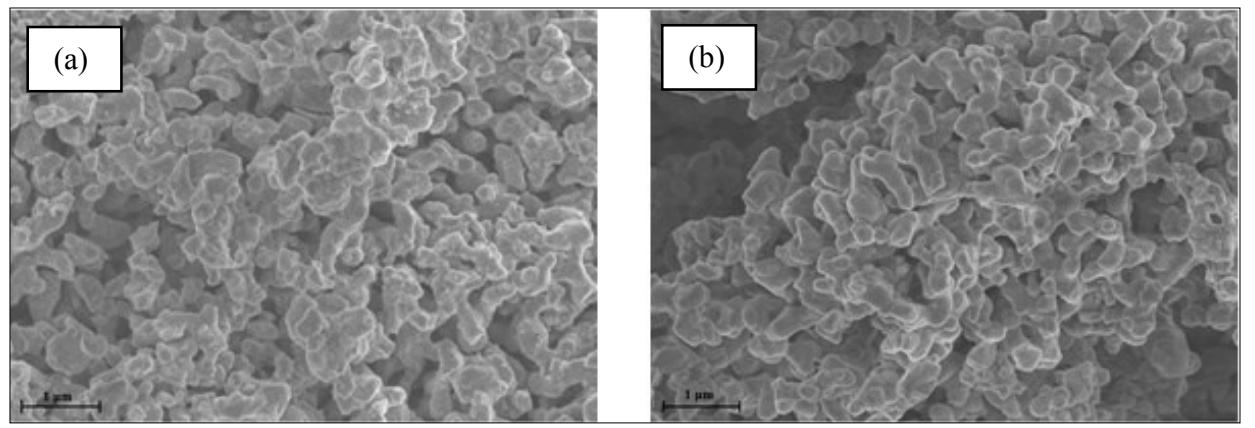

Figure 3. SEM micrographs of (a) EG900 powder and (b) AC900 powder

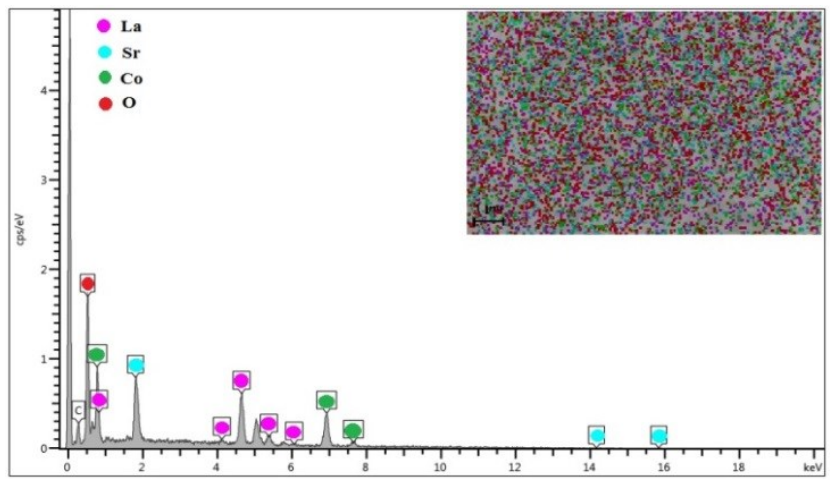

Figure 4. EDX spectrum of EG900 powder

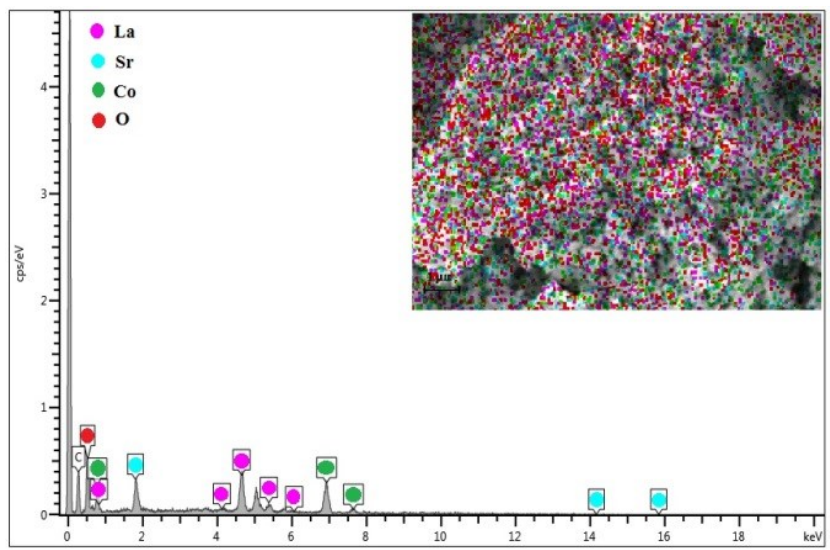

Figure 5. EDX spectrum of AC900 powder 
Abdullah et al: PREPARATION OF LANTHANUM STRONTIUM COBALT OXIDE POWDER BY A MODIFIED SOL-GEL METHOD

Table 2. EDX data of weight percentage (wt \%) and Mole fraction for EG900 powder

\begin{tabular}{lccccc}
\hline Element & Wt. \% & Formula Wt. & Mole & $\begin{array}{c}\text { Calculated Mole } \\
\text { Fraction }\end{array}$ & $\begin{array}{c}\text { Nominal Mole } \\
\text { Fraction }\end{array}$ \\
\hline $\mathrm{La}$ & 37.15 & 138.905 & 0.267 & 0.61 & 0.60 \\
$\mathrm{Sr}$ & 12.65 & 87.620 & 0.144 & 0.33 & 0.40 \\
$\mathrm{Co}$ & 25.65 & 58.933 & 0.435 & 1.00 & 1.00 \\
& & & & $\mathbf{1 . 9 4}$ & $\mathbf{2 . 0 0}$ \\
$\mathrm{O}$ & 17.75 & 15.999 & 1.109 & & \\
$\mathrm{C}$ & 6.80 & 12.011 & 0.566 & & \\
\hline
\end{tabular}

Table 3. EDX data of weight percentage (wt \%) and mole fraction for AC900 powder

\begin{tabular}{lccccc}
\hline Element & Wt. \% & Formula Wt & Mole & $\begin{array}{c}\text { Calculated Mole } \\
\text { Fraction }\end{array}$ & $\begin{array}{c}\text { Nominal Mole } \\
\text { Fraction }\end{array}$ \\
\hline $\mathrm{La}$ & 36.20 & 138.905 & 0.261 & 0.56 & 0.60 \\
$\mathrm{Sr}$ & 11.00 & 87.620 & 0.126 & 0.27 & 0.40 \\
$\mathrm{Co}$ & 27.45 & 58.933 & 0.466 & 1.00 & 1.00 \\
& & & & $\mathbf{1 . 8 3}$ & $\mathbf{2 . 0 0}$ \\
$\mathrm{O}$ & 13.65 & 15.999 & 0.853 & & \\
$\mathrm{C}$ & 11.60 & 12.011 & 0.966 & & \\
\hline
\end{tabular}

Table 4 shows the average particle size of secondary particles for EG900 and AC900 powders measured using PSA. It can be seen that the average particle size of the EG900 is smaller than the average particle size of the AC900. The bimodal particle size distribution of the EG900 and AC900 powders are shown in Figure 6 and Figure 7, respectively. Two groups of particle size were observed in the particle size distribution for both samples. For EG900, the powder sample showed about $\sim 87 \%$ of its particles lying between $\sim 450$ and $1300 \mathrm{~nm}$ and only $\sim 13 \%$ in the $\sim 160-340 \mathrm{~nm}$ range. For AC900, the powder sample showed about $85 \%$ of its particles lying between $\sim 530$ and $1300 \mathrm{~nm}$ and only $15 \%$ in the $\sim 190-400 \mathrm{~nm}$ range. The difference in the particle size diameter and particle size distribution between both powders might be resulted from the properties of the surfactants used as they have different molecular structure and different relative bond strength towards compound (metal cations) during synthesizing process. Besides that, surfactant complexes concentration might also contribute to the results as it affects particle growth pathways which then leading to various morphologies.

Table 4. Average particle size diameter of EG900 and AC900 powders measured using PSA

\begin{tabular}{cc}
\hline Sample & $\begin{array}{c}\text { Average Particle Size Diameter } \\
(\mathbf{n m})\end{array}$ \\
\hline EG900 & 751.2 \\
AC900 & 1046.3 \\
\hline
\end{tabular}




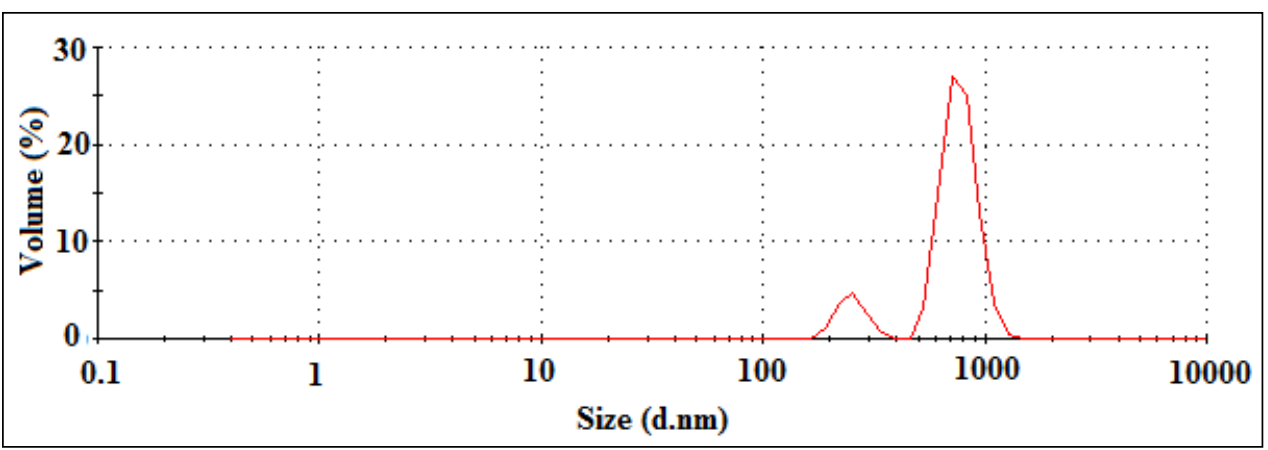

Figure 6. The bimodal particle size distribution of the EG900 powders

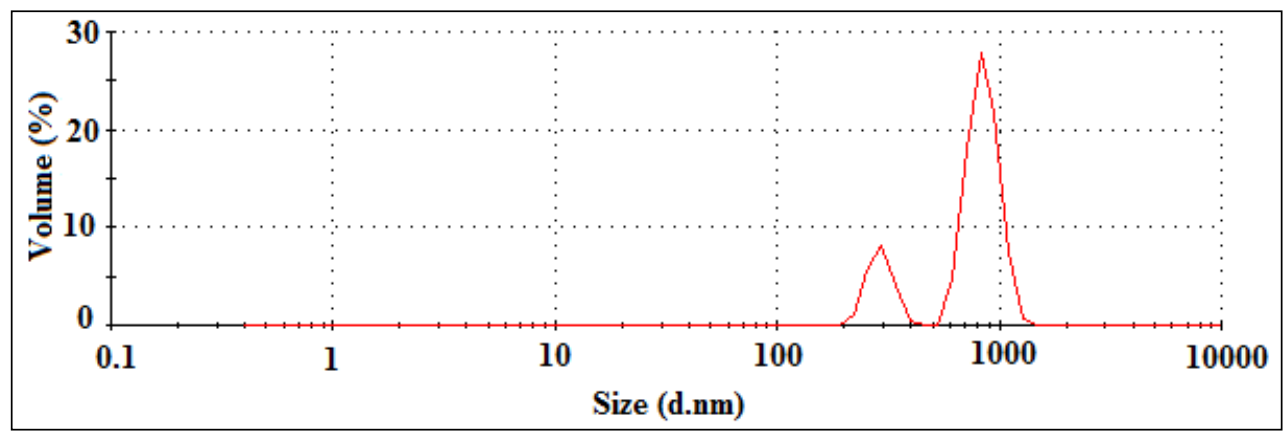

Figure 7. The bimodal particle size distribution of the AC900 powders

Table 5 shows the comparison of particle size diameter of primary particles obtained from this work with another reported works. It can be seen that the particle size obtained from this work is bigger than those reported works. The discrepancy between the results is due to the different synthesis methods and chemical agents used such as chelating agent, fuel or surfactant for the production of LSCO-based powders. The different synthesis methods with different chemical agents will produce materials with different microstructures and properties. Additionally, all the reported works have optimized or controlled their synthesizing parameters such as the amount of surfactant, $\mathrm{pH}$ and others in order to produce the nano-size powder but not for this work. Therefore, to obtain the nano size particles $(<100 \mathrm{~nm})$ of LSCO, the relative bond strength and concentration of surfactant will be studied and controlled in our future work and the progress will be reported elsewhere.

Table 5. Average particle size diameter of LSCO powders produced by various methods

\begin{tabular}{llccc}
\hline Synthesis method & Chemical agent & $\begin{array}{c}\text { Calcination } \\
\text { temperature }\left({ }^{\circ} \mathbf{C}\right)\end{array}$ & $\begin{array}{c}\text { Average particle } \\
\text { size diameter } \\
(\mathbf{n m})\end{array}$ & Reference \\
\hline Modified sol-gel & EG as surfactant & 900 & $\sim 149^{\mathrm{a}}$ & [This work] \\
& AC as surfactant & 900 & $\sim 190^{\mathrm{b}}$ & \\
Solution-combustion & Glycine as fuel & 1100 & 50 & {$[13]$} \\
\hline
\end{tabular}


Table 5 (cont'd). Average particle size diameter of LSCO powders produced by various methods

\begin{tabular}{llccc}
\hline Synthesis method & Chemical agent & $\begin{array}{c}\text { Calcination } \\
\text { temperature }\left({ }^{\circ} \mathbf{C}\right)\end{array}$ & $\begin{array}{c}\text { Average particle } \\
\text { size diameter } \\
(\mathbf{n m})\end{array}$ & Reference \\
\hline Citrate-EDTA & $\begin{array}{l}\text { Poly-EG as } \\
\text { surfactant }\end{array}$ & 900 & 60 & {$[8]$} \\
Flame spray & Acetic acid as fuel & 900 & 50 & {$[11]$} \\
Citrate complexing & $\begin{array}{l}\text { Citric acid as } \\
\text { complexing agent }\end{array}$ & 1100 & $150-250$ & {$[12]$} \\
$\begin{array}{l}\text { Metal organic } \\
\text { deposition }\end{array}$ & $\begin{array}{l}\text { Propionic acid as } \\
\text { chelating agent }\end{array}$ & 700 & $17-90$ & {$[14]$} \\
\hline
\end{tabular}

${ }^{\mathrm{a}, \mathrm{b}}$ measured using image processing software from SEM analysis

\section{Conclusion}

LSCO powders was successfully prepared using a modified sol-gel method with different surfactants namely ethylene glycol (EG) and activated carbon (AC). A single perovskite phase of LSCO was obtained at calcination temperature of $900{ }^{\circ} \mathrm{C}$ for both surfactants as confirmed by XRD measurement. The pure phase powders of EG900 and AC900 obtained consists of uniform particle size with almost identical spherical shape as revealed by the SEM analysis. EDX measurement confirmed the presence of $\mathrm{La}, \mathrm{Sr}, \mathrm{Co}, \mathrm{O}$ and $\mathrm{C}$ elements in both powders. Elemental fraction of $\mathrm{La} / \mathrm{Sr}$ in the AC900 powder is slightly deviated from its nominal fraction. Both of the powders have different particle size diameter and particle size distribution as confirmed by particle size analyzer. The EG900 and AC900 powders have average particle size diameter of $751.2 \mathrm{~nm}$ and $1046.3 \mathrm{~nm}$ for secondary particles, and 149 $\mathrm{nm}$ and $190 \mathrm{~nm}$ for primary particle, respectively. Proton conducting SOFC cathode fabricated using EG900 powder is expected to perform better than AC900 powder due to the fact that the former has finer particle size with reduced residual carbon.

\section{Acknowledgement}

The authors would like to thank the Ministry of Higher Education (MOHE) for the Fundamental Research Grant Scheme (FRGS/2/2013/TK06/UKM/02/9) and Universiti Kebangssan Malaysia (UKM) via research sponsorship of DLP-2014-004. Abdullah Abdul Samat is thankful to MOHE and Universiti Malaysia Perlis (UniMAP) for the SLAB/SLAI scholarship. Facility support from Center for Research and Instrumentation Management (CRIM) of UKM and Universiti Teknologi MARA (UiTM) is gratefully acknowledged.

\section{References}

1. Tao, Z., Bi, L., Yan, L., Sun, W., Zhu, Z., Peng, R. and Liu, W. (2009). A novel single phase cathode material for a proton-conducting SOFC. Electrochemical Communication, 11(3): 688 - 690.

2. Handal, H. T. and Thangadurai, V. (2013). Evaluation of chemical stability, thermal expansion coefficient, and electrical properties of solid state and wet-chemical synthesized $\mathrm{Y}$ and $\mathrm{Mn}$-codoped $\mathrm{CeO}_{2}$ for solid oxide fuel cells. Journal of Power Sources, 243: 458 - 471.

3. Bi, L., Fabbri, E. and Traversa, E. (2012). Novel $\mathrm{Ba}_{0.5} \mathrm{Sr}_{0.5}\left(\mathrm{Co}_{0.8} \mathrm{Fe}_{0.2}\right)_{1-\mathrm{x}} \mathrm{Ti}_{\mathrm{x}} \mathrm{O}_{3-\delta}(\mathrm{x}=0,0.05$, and 0.1) cathode materials for proton-conducting solid oxide fuel cells. Solid State Ionics, 214: $1-5$.

4. Goupil, G., Delahaye, T., Gauthier, G., Sala, B. and Joud, F. L. (2012). Stability study of possible air electrode materials for proton conducting electrochemical cells. Solid State Ionics, 209 - 210: 36 - 42.

5. Ling, Y., Wang, F., Zhao, L., Liu, X. and Lin, B. (2014). Comparative study of electrochemical properties of different composite cathode materials associated to stable proton conducting $\mathrm{BaZr}_{0.7} \mathrm{Pr}_{0.1} \mathrm{Y}_{0.2} \mathrm{O}_{3-\delta}$ electrolyte. Electrochimica Acta, 146: 1 - 7.

6. Yu, T., Mao, X. and Ma, G. (2014). Performance of cobalt-free perovskite $\mathrm{La}_{0.6} \mathrm{Sr}_{0.4} \mathrm{Fe}_{1-\mathrm{x}} \mathrm{Nb}_{\mathrm{x}} \mathrm{O}_{3-\delta}$ cathode materials for proton-conducting IT-SOFC. Journal Alloys Compounds, 608: 30 - 34. 
7. Tolchard, J. R. and Grande, T. (2007). Chemical compatibility of candidate oxide cathodes for $\mathrm{BaZrO}_{3}$ electrolytes. Solid State Ionics, 178(7-10): 593 - 599.

8. Tao, Y., Shao, J., Wang, J. and Wang, W.G. (2008). Synthesis and properties of $\mathrm{La}_{0.6} \mathrm{Sr}_{0.4} \mathrm{CoO}_{3-\delta}$ nanopowder, Journal of Power Sources, 185(2): 609 - 614.

9. Shao, Z., Zhou, W. and Zhu, Z. (2012). Advanced synthesis of materials for intermediate-temperature solid oxide fuel cells. Progress in Materials Science, 57(4): 804 - 874.

10. Wongmaneerung, R., Yimnirun, R. and Ananta, S. (2009). Effect of two-stage sintering on phase formation, microstructure and dielectric properties of perovskite PMN ceramics derived from a corundum $\mathrm{Mg}_{4} \mathrm{Nb}_{2} \mathrm{O}_{9}$ precursor. Materials Chemistry and Physics, 114(2-3): 569 - 575.

11. Heel, A., Holtappels, P. and Graule, T. (2010). On the synthesis and performance of flame-made nanoscale $\mathrm{La}_{0.6} \mathrm{Sr}_{0.4} \mathrm{CoO}_{3-\delta}$ and its influence on the application as an intermediate temperature solid oxide fuel cell cathode. Journal of Power Sources, 195(19): 6709 - 6718.

12. Acuña, L. M., Peña-Martínez, J., Marrero-López, D., Fuentes, R. O., Nuñez, P. and Lamas, D.G. (2011). Electrochemical performance of nanostructured $\mathrm{La}_{0.6} \mathrm{Sr}_{0.4} \mathrm{CoO}_{3-\delta}$ and $\mathrm{Sm}_{0.5} \mathrm{Sr}_{0.5} \mathrm{CoO}_{3-\delta}$ cathodes for IT-SOFCs. Journal of Power Sources, 196(22): 9276 - 9283.

13. Bansal, N. P. and Zhong, Z. (2006). Combustion synthesis of $\mathrm{Sm}_{0.5} \mathrm{Sr}_{0.5} \mathrm{CoO}_{3-\mathrm{x}}$ and $\mathrm{La}_{0.6} \mathrm{Sr}_{0.4} \mathrm{CoO}_{3-\mathrm{x}}$ nanopowders for solid oxide fuel cell cathodes. Journal of Power Sources, 158(1): 148 - 153.

14. Hayd, J., Dieterle, L., Guntow, U., Gerthsen, D. and Ivers-Tiffée, E. (2011). Nanoscaled $\mathrm{La}_{0.6} \mathrm{Sr}_{0.4} \mathrm{CoO}_{3-\delta}$ as intermediate temperature solid oxide fuel cell cathode: Microstructure and electrochemical performance. Journal of Power Sources, 196(17): 7263 - 7270. 